PARASITOLOGY is published in double issues twice a year. The numbers afterwards are issued in volumes each containing four numbers.

Papers for publication should be sent to Professor D. KEIrN, Molteno Institute, Downing Street, Cambridge. Other communications should be addressed to the University Press, Cambridge.

Papers forwarded to the Editors for publication are understood to be offered to PARASITOLOGY alone, unless the contrary is stated.

Contributors receive fifty copies of their papers free. Additional copies, not exceeding one hundred (except in special cases), may be had at cost price: these should be ordered when the final proof is returned.

The subscription price, payable in advance, is $£ 5$ net per volume, post-free (U.S.A. \$17.00), double numbers 55s. net, postage extra (U.S.A. \$9.50). Subscriptions may be sent to any Bookseller, or to The Cambridge University Press, Bentley House, 200 Euston Road, N.W. 1.

Enquiries from the U.S.A. should be addressed to the American Branch of the Press at 32 East 57th Street, New York, 22.

\title{
BIOLOGICAL ASPECTS OF THE TRANSMISSION OF DISEASE
}

\section{Edited by C. HORTON-SMITH}

This volume contains 22 pages (with discussions) given at a symposium organised by the Institute of Biology with the object of bringing together botanists, zoologists and human and veterinary pathologists on common ground.

The papers are arranged in groups corresponding with the mode of transmission of disease-direct, indirect or cyclical. This arrangement was welcomed by those who attended the symposium and should provide a stimulus to the thoughts of those who read this volume.

\section{1s. net}

Published for the Institute of Biology

\section{OLIVER \& BOYD: TWEDDALE COURT,}




\section{O N T E N T S}

(All rights reserved)

GibBs, Alfrep J. Leptomonas serpens n.sp., parasitic in the digestive tract and salivary glands of Nezara viridula (Pentatomidae) and in the sap of Solanum lycopersicum (tomato) and other plants. (With 1 Figure in the Text) . .

Crofton, H. D. Nematode parasite populations in sheep on lowland farms. III. The seasonal incidence of species. (With 9 Figures in the Text) . . . .

BIRD, ALan F, and Deutsoh, KARL. The structure of the cuticle of Ascaris lumbricoides var. suis. (With Plates XIV-XVI).

Tru, W. M. Two new parasitic mites (Acarina) from the South African porcupine. (With 6 Figures in the Text)

Dissanatke, A. S. The morphology and life cycle of Nosema helminthorum Moniez, 1887. (With 39 Figures in the Text)

Arthur, Don. R. The male of Ixodes thompsoni Arthur, 1955. (With 7 Figures in the Text)

Sprent, J.F.A. A new species of Neoascaris from Rattus assimilis, with a redefinition of the genus. (With Plate XVII and 10 Figures in the Text) . . . .

Fosmer, R. Observations on laboratory colonies of the tsetse flies Glossina morsitans West. and Glossina austeni Newstead

Solrys, M. A. Immunity in trypanosomiasis. I. Neutralization reaction. (With 1 Figure in the Text)

Solrys, M. A. Immunity in trypanosomiasis. II. Agglutination reaction with African trypanosomes. (With 1 Figure in the Text)

Cragg, J. B., Foster, R. and Vincent, M. Larval trematodes (Brachylaemidae) from the slugs Milax sowerbii (Férussac), Agriolimax reticulatus (Müller) and Arion lusitanicus Mabille. (With 5 Figures in the Text)

JAYeWARDENE, L. G. The merthiolate iodine formaldehyde concentration technique for the detection of parasitic material in faecal samples

Mrcherson, EDward H. Studies on the biological control of schistosome-bearing snails. Predators and parasites of fresh-water mollusca : a review of the literature

Wotron, R. M. and Halsey, H. R. The ingestion of particulate fat from the blood by Trypanosoma lewisi and Trypanosoma equiperdum. (With 1 Figure in the Text)

LIANG-SHeng, YeH. On a new paramphistomid trematode, Gigantocotyle lerouxi sp.n. from the stomach of the red lechwe, Onotragus leche from Northern Rhodesia. (With 2 Figures in the Text)

Prtce, Roger D. A microscopic study of Pasteurella tularensis in the human body louse. (With Plate XVIII and 1 Figure in the Text)

Humes, Arthur G. Lamippe concinna sp.n., a copepod parasitic in a West African pennatulid coelenterate. (With 13 Figures in the Text)

Gurta, P. D. On Psilochasmus indious, sp.n. (family Psilostomidae Odhner, 1913). (With 1 Figure in the Text)

Theodor, Oskar. The Nycteribiidae of the Ethiopian Region and Madagascar. (With 129 Figures and 3 Maps in the Text)

ArThUr, D. R. The Ixodes schillingsi group: ticks of Africa and Madagasear, parasitic on primates, with descriptions of two new species (Ixodoidea, Ixodidae). (With 37 Figures in the Text) .

Index of Authors

Index of Subjects 